\title{
A FEKVŐ HOLTFA MENNYISÉGI ÉS MINŐSÉGI BECSLÉSE A SOPRONI HEGYVIDÉK KÉT PATAKVÖLGYÉBEN
}

\author{
Komlós Mariann és Kiss Csilla \\ Soproni Egyetem, Vadgazdálkodási és Gerinces Állattani Intézet
}

\begin{abstract}
Kivonat
A Soproni-hegység két patakvölgyében, a Tolvaj-és a Vadkan-árokban vizsgáltuk a fekvő holtfa mennyiségi és minőségi jellemzőit. A patakvölgyek keresztmetszetében transzektek mentén történt a fekvő holt faanyag felvételezése. Megállapítottuk, hogy összességében a Tolvaj-árokban magasabb a fekvő holt faanyag aránya (30,66 m³/ha, míg a Vadkan-árokban $21,23 \mathrm{~m}^{3} / \mathrm{ha}$ ), valamint, hogy a holtfa korhadási fázis, átmérő és fafaj szerinti megoszlása jelentős heterogenitást mutatott a területen. A korcsoportok szerinti vizsgálat eredménye egyezik az általunk elvárttal, azaz az állomány korának előrehaladtával a fekvő holtfa mennyisége is nő, a potenciális élőhelyeket vizsgálva pedig a legtöbb holtfát a gyertyános kocsánytalan tölgyesekben találtuk.
\end{abstract}

Kulcsszavak: fekvő holtfa, Soproni-hegység, vonal menti mintavétel

\section{ESTIMATION OF THE FALLEN DEAD WOOD IN THE SOPRON MOUNTAINS}

\begin{abstract}
In this paper we have analyzed the quantitative and qualitative dispersion of lying dead wood in two streambeds of the Sopron Mountains, the Tolvaj-árok and the Vadkan-árok. The estimation of the lying dead wood was made with the line transect method by perpendicular transects at the two valleys. The amount of dead wood was higher $\left(30,66 \mathrm{~m}^{3} / \mathrm{ha}\right)$ in the Tolvaj-árok compared to the Vadkan-árok $(21,23 \mathrm{~m} / \mathrm{ha})$. The distribution of dead wood showed strong heterogenity on the study area for the three studied parameters (decay stage, diameter and tree species). The amount of fallen dead wood increased with stand age. Concerning forest communities, the largest amount of dead wood has been found in the sessile oak-hornbeam forests.
\end{abstract}

Keywords: lying deadwood, Sopron Mountains, line intersect method 


\section{BEVEZETÉS}

A holtfa kutatása a 2000-es évek során lendült fel, a folyamatos erdőborítás, a természetközeli erdőgazdálkodás és az erdörezervátumok kutatásának élénkülésével, és azok kulcsszerepének nyilvánvalóvá válásával. Mára számos nemzetközi és hazai vizsgálat hívja fel a figyelmet a holt faanyag nélkülözhetetlen és sokrétủ szerepére az erdei ökoszisztémákban (Hodge \& Peterken 1998, Winkler 2000, 2005, Kraigher et al 2003, Ódor \& Standovár 2003, Schuck et al 2004, Stockland et al 2004, Bobiec et al 2005, Johnsson et al 2005, Dynesius et al 2010, Jakoby et al 2010, Merganicová et al 2012, Frank \& Szmorad 2014, Ónodi \& Winkler 2014, Tóth 2014, Bölöni et al 2015, Merkl 2016, Mikó \& Csóka 2016, Ódor 2016). Ennek ellenére még mindig sok kérdés maradt dinamikáját, keletkezését, kivánatos és minimális mennyiségét, a hozzá kötődő élölények sokaságát, valamint az erdő egyéb alkotóelemeivel való kölcsönhatását illetően.

A holtfa kialakulásában és felhalmozódásában nagyszámú tényező játszik közre, mint például a fa életkora és faja, a környezet biotikus és abiotikus jellemzői (Schuck et al 2004, Bobiec et al 2005, Merganicová et al 2012).

A holtfa kulcsszerepet tölt be az erdei ökoszisztémák összetételében. Ódor (2016) szerint az erdei fajok több mint fele kötődik hozzá valamilyen módon. A holt faanyagon megjelenő fajok jelenléte, abundanciája szempontjából annak korhadtsági foka, átmérője is meghatározó, ezért fontos, hogy előfordulása megfelelően diverz legyen egy adott területen (Stockland et al 2004, Johnsson et al 2005, Mag \& Ódor 2015, Sefidi \& Etemad 2015, Merkl 2016, Keren \& Diaci 2018).

A holtfa mennyisége többek között függ az adott terület éghajlatától, termőhelyi jellemzöitöl, az erdőciklusban betöltött fázisától, fafajától, a múltbeli és jelenlegi kezelések módjától és a bolygatási rezsimtől (Kirby et al 1998, Somogyi 1998, Ódor et al 2004, Christensen et al 2005, Vacek et al 2015). A kezelt erdőkben jelentősen kevesebb a holtfa mennyisége és legtöbb esetben minősége sem megfelelö, mivel a kitermelt faanyagot sokszor teljes mértékben eltávolítják a területröl, csak a vékony holtfa marad vissza (Kirby et al 1998, Odor \& Standovár 2003, Christensen et al 2005, Csóka 2011, Bölöni et al 2015). Ugyanakkor ezekből az erdőkből jóval kevesebb adattal is rendelkezünk, mivel a holtfa felmérésére irányuló munkák nagy része rezervátumokból és őserdö-szerü állományokból származik (Ódor \& Standovár 2003, Christensen et al 2005, Bölöni et al 2015).

A föld feletti elhalt faanyagot mérete alapján két csoportba oszthatjuk: finom- (fine woody debris, FWD, ált. $<5 \mathrm{~cm}$ ) és durva fa törmelék (coarse woody debris, $C W D,>5 \mathrm{~cm}$ ). A legtöbb szerző az álló és fekvő holtfa közötti határt 45-ban határozza meg (Ódor 2005, Rondeux \& Sanchez 2009, Merganicová et al 2012).

A holtfának komoly szerepe van az erózió megelőzésében, a talaj nedvességtartalmának megőrzésében, az erdő tápanyagforgalmában, a különböző vízfolyások alakításában és védelmében, valamint szerepe lehet az erdő felújulásában is (Hodge \& Peterken 1998, Kirby et al 1998, Kraigher et al 2003, Bobiec et al 2005, Merganicová et al 2012, Bidló \& Szücs 2014, Tóth 2014).

Megítélése továbbra is ellentmondásos: egyesek szerint erdővédelmi kockázatot jelent és eltávolítandó, míg mások nélkülözhetetlen szerepéről beszélnek és a lehetőségek szerinti legtöbb faanyag visszahagyását támogatják (Lakatos 2006, Merganicová et al 2012, Frank \& Szmorad 2014, Preiksa et al 2015, Merkl 2016, Ódor 2016, Tímár 2016, Svensson et al 2016, De Meo et al 2017). A különböző - természetvédelmi és gazdasági - szempontok összeegyeztethetősége és a hézagok kitöltése érdekében további célirányos kutatásokra van szükség.

Kutatásunkban a Soproni-hegység két patakvölgyében, a Tolvaj-árokban és a Vadkan-árokban vizsgáltuk a fekvő holtfa mennyiségi és minőségi jellemzőit. Az alábbi kérdésekre kerestük a választ: van-e kimutatható különbség a hegység két különböző klímájú részén található patakvölgy között a holtfa paramétereket tekintve? A különböző potenciális vegetációtípusonként között milyen eltérések fedezhetök fel a holtfa minőségi paramétereinek megoszlásában? Az állományok kora milyen hatással van a holt faanyag eloszlására? 


\section{ANYAG ÉS MÓDSZER}

\section{A vizsgálati terület bemutatása}

Vizsgálatainkat a Soproni-hegységben végeztük. A hegység klímazonális vegetációtípusa üde lombos erdők, a Brennbergbánya-Görbehalom vonalig bükkösök, attól keletre gyertyános-tölgyesek fordulnak elő. Völgyeiben kiterjedt égerligetek találhatók, emellett számottevő a mészkerülő lomberdők jelenléte. Erdeiben igen erős emberi hatás érvényesült évszázadokig, emiatt természetszerủ állományok alig találhatóak. Az erdők leromlásának megállitására telepítettek be luc-, vörös és feketefenyőt a talaj javitásának céljából, ennek eredményeként ma is jelentős a fenyők térfoglalása a területen (Király 2004, 2008, Dövényi 2010, Szmorad 2011).

A Soproni-hegységet két, markánsan elkülönülö részre lehet osztani mind geomorfológiai, mind éghajlati és növényföldrajzi szempontból (Király 2004, Szmorad 2011). E két részt reprezentálja a Tolvaj- és a Vadkanárok, melyben vizsgálatainkat végeztük (1. ábra).

A Vadkan-árok a Rák-patak egyik jobb oldali mellékágát képezi, a Hidegvíz-völgyben található. Hossza $1340 \mathrm{~m}$, területe mintegy 36 ha, nagy része a $20^{\circ}$ feletti lejtőkategóriába esik, vízfolyása állandó. A Hidegvízvölgyben a montán-szubmontán hatás kifejezett, a középhömérséklet $10^{\circ} \mathrm{C}$ alatti. Ez a hegyvidék legkevésbé zavart tájegysége, sok a fokozottan védett terület. A korábbi határzár következtében a nem elégséges ápolások miatt a betelepített fenyvesek leromlottak, a tarvágások eredményeként visszatelepülhettek az őshonos fajok, melyek területaránya nőtt (Bolla 2007, Bartha \& Oroszi 2011).
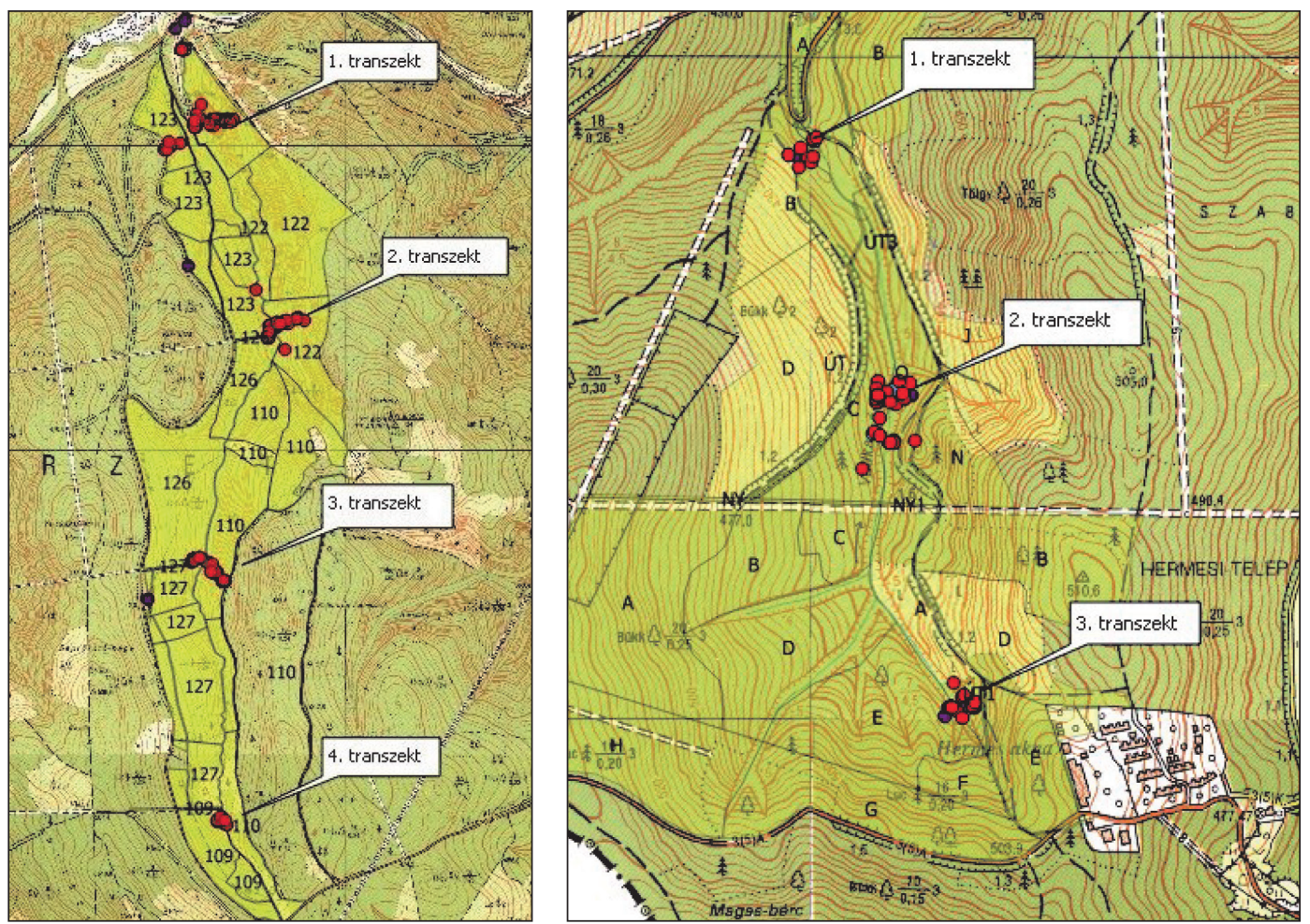

1. ábra: A Tolvaj-árok (a) és a Vadkan-árok (b) területén kijelölt mintapontok elhelyezkedése

Figure 1: Sample points of the Tolvaj-árok (a) and the Vadkan-árok (b) in the Sopron Mountains 
Az érintett erdőrészletek a következők: Sopron 162A, 163B, 1630, 168B, 168C és 169E (1. táblázat). Elsődleges rendeltetésük természetvédelmi, valamint Natura 2000. Üzemmódjuk nagyobbrészt átalakító, emellett pedig vágásos, természetvédelmi részleges korlátozással. Az állományok átlagos kora a fiatalostól (6-7 év) a 112 évesig terjed.

A Tolvaj-árok a Várhelyi tájegységben található, mélyen bevágódott völgy, hossza mintegy $2,5 \mathrm{~km}$, területe mintegy 96 ha. Az árokban futó vízfolyás a Rák-patak egyik mellékága. A terület meredeksége néhol a $25^{\circ}$-ot is eléri (Bartha \& Oroszi 2011).

1. táblázat: $A$ Vadkan-árok vizsgálatban érintett erdőrészleteinek adatai

Table 1: Characteristics of the concerned forest stands in Vadkan-árok

\begin{tabular}{|c|c|c|c|c|c|c|c|}
\hline $\begin{array}{l}\text { Vadkan- } \\
\text { árok }\end{array}$ & $\begin{array}{c}\text { Terület } \\
\text { (ha) }\end{array}$ & Kor & $\begin{array}{l}\text { Faállomány- } \\
\text { típus }\end{array}$ & $\begin{array}{l}\text { Fafaj- } \\
\text { összetétel }\end{array}$ & $\begin{array}{c}\text { Utolsó } \\
\text { használat }\end{array}$ & $\begin{array}{l}\text { Potenciális } \\
\text { erdő-társulás }\end{array}$ & $\begin{array}{l}\text { Minta } \\
\text { pontok } \\
\text { száma }\end{array}$ \\
\hline \multirow[t]{2}{*}{$162 \mathrm{~A}$} & \multirow[t]{2}{*}{2,12} & felső Isz: 28 & \multirow[t]{2}{*}{$B-F$} & $\begin{array}{l}\text { B } 73 \% \\
\text { LF } 16 \% \\
\text { VF } 11 \%\end{array}$ & \multirow{2}{*}{$\begin{array}{l}\text { egészségügyi } \\
\text { fakitermelés } \\
(2012)\end{array}$} & égerliget & 1 \\
\hline & & alsó Isz: 4-5 & & $\begin{array}{l}\text { B } 90 \% \\
\text { LF } 10 \%\end{array}$ & & montán bükkös & 1 \\
\hline 163B & 3,82 & felső Isz: 112 & GY-KTT-EL & $\begin{array}{l}\text { KTT } 25 \% \\
\text { GY } 30 \% \\
\text { LF } 8 \% \\
\text { B } 37 \%\end{array}$ & $\begin{array}{l}\text { tarvágás } \\
(2005)\end{array}$ & égerliget & 1 \\
\hline \multirow[b]{2}{*}{1630} & \multirow[b]{2}{*}{2,25} & \multirow[b]{2}{*}{$82-102$} & \multirow[b]{2}{*}{ GY-E } & GY 45\% & \multirow[b]{2}{*}{$\begin{array}{l}\text { növedék-fokozó } \\
\text { gyérítés } \\
(2005)\end{array}$} & égerliget & 1 \\
\hline & & & & $\begin{array}{l}\text { MÉ 27\% } \\
\text { HJ 11\% } \\
\text { CSNY 2\% } \\
\text { KTT 7\% } \\
\text { B 5\% } \\
\text { LF 3\% }\end{array}$ & & montán bükkös & 1 \\
\hline \multirow[b]{2}{*}{ 168B } & \multirow[b]{2}{*}{2,77} & \multirow[b]{2}{*}{28} & \multirow[b]{2}{*}{ B-GY } & B 52\% & \multirow[b]{2}{*}{$\begin{array}{l}\text { tisztítás } \\
\text { (2011) }\end{array}$} & égerliget & 1 \\
\hline & & & & $\begin{array}{l}\text { GY } 11 \% \\
\text { HJ } 7 \% \\
\text { VF15\% } \\
\text { LF } 15 \%\end{array}$ & & montán bükkös & 1 \\
\hline \multirow{2}{*}{$168 C$} & \multirow[b]{2}{*}{2,7} & \multirow[b]{2}{*}{42} & \multirow[b]{2}{*}{ LF-EL } & LF 68\% & \multirow{2}{*}{$\begin{array}{l}\text { törzskiválasztó } \\
\text { gyérítés } \\
(2009)\end{array}$} & égerliget & 1 \\
\hline & & & & $\begin{array}{l}\text { GY } 22 \% \\
\text { MK 5\% } \\
\text { B 5\% }\end{array}$ & & montán bükkös & 1 \\
\hline \multirow[b]{2}{*}{$169 \mathrm{E}$} & \multirow[b]{2}{*}{4,15} & \multirow[b]{2}{*}{$45-50$} & \multirow{2}{*}{$L F-B$} & LF $51 \%$ & \multirow{2}{*}{$\begin{array}{l}\text { egészségügyi } \\
\text { fakitermelés } \\
(2015)\end{array}$} & égerliget & 1 \\
\hline & & & & $\begin{array}{l}\text { B 19\% } \\
\text { MÉ 16\% } \\
\text { KNY 14\% }\end{array}$ & & montán bükkös & - \\
\hline
\end{tabular}

A mintavételi pontok az alábbi erdőrészletekben találhatóak: Sopron 109E, 110G, 110M, 122A, 122D, $123 \mathrm{E}, 123 \mathrm{H}$ és 126E (2. táblázat). Az erdőrészletek elsődleges rendeltetése túlnyomóan természetvédelmi, emellett főként tanerdő és parkerdő rendeltetésűek, üzemmódjuk nagyobbrészt vágásos. Az állományok átlagos kora az igen fiataltól (8-9 év) a 117 évesig terjed, többségük 60-80 év körüli. 
2. táblázat: $A$ Tolvaj-árok vizsgálatban érintett erdőrészleteinek adatai

Table 2: Characteristics of the concerned forest stands in Tolvaj-árok

\begin{tabular}{|c|c|c|c|c|c|c|c|}
\hline $\begin{array}{l}\text { Tolvaj- } \\
\text { árok }\end{array}$ & $\begin{array}{l}\text { Terület } \\
\text { (ha) }\end{array}$ & Kor (év) & $\begin{array}{l}\text { Faállomány- } \\
\text { típus }\end{array}$ & $\begin{array}{c}\text { Fafaj- } \\
\text { összetétel }\end{array}$ & $\begin{array}{c}\text { Utolsó } \\
\text { használat }\end{array}$ & $\begin{array}{l}\text { Potenciális } \\
\text { erdö-társulás }\end{array}$ & $\begin{array}{c}\text { Minta } \\
\text { pontok } \\
\text { száma }\end{array}$ \\
\hline \multirow[b]{2}{*}{ 109E } & \multirow[b]{2}{*}{3,99} & \multirow[b]{2}{*}{35} & \multirow[b]{2}{*}{ VF } & \multirow{2}{*}{$\begin{array}{l}\text { VF } 55 \% \\
\text { LF } 13 \% \\
\text { B } 32 \%\end{array}$} & \multirow{2}{*}{$\begin{array}{l}\text { egészségügyi } \\
\text { fakitermelés } \\
(2015)\end{array}$} & égerliget & 1 \\
\hline & & & & & & $\begin{array}{l}\text { szubmontán } \\
\text { bükkös }\end{array}$ & 1 \\
\hline \multirow[t]{2}{*}{$110 \mathrm{G}$} & \multirow[t]{2}{*}{6,46} & felső Isz: 67 & \multirow[t]{2}{*}{ EF-B } & $\begin{array}{l}\text { EF } 55 \% \\
\text { B } 17 \% \\
\text { KTT } 14 \% \\
\text { GY 7\% } \\
\text { VF 4\% } \\
\text { SZG 3\% }\end{array}$ & \multirow[t]{2}{*}{$\begin{array}{l}\text { tarvágás } \\
\text { (2007) }\end{array}$} & égerliget & 1 \\
\hline & & alsó Isz: 8-9 & & $\begin{array}{l}\text { EF } 60 \% \\
\text { KTT 35\% } \\
\text { B 5\% }\end{array}$ & & $\begin{array}{l}\text { szubmontán } \\
\text { bükkös }\end{array}$ & 2 \\
\hline \multirow{2}{*}{$110 \mathrm{M}$} & \multirow{2}{*}{3,26} & \multirow{2}{*}{19} & \multirow{2}{*}{ GY-KTT-F } & \multirow{2}{*}{$\begin{array}{l}\text { KTT } 60 \% \\
\text { B } 2 \% \\
\text { VF } 16 \% \\
\text { LF } 5 \% \\
\text { EF } 1 \% \\
\text { GY } 16 \%\end{array}$} & \multirow{2}{*}{ (1998) } & égerliget & 1 \\
\hline & & & & & & $\begin{array}{l}\text { szubmontán } \\
\text { bükkös }\end{array}$ & - \\
\hline \multirow[b]{2}{*}{$122 \mathrm{~A}$} & \multirow[b]{2}{*}{5,44} & \multirow[b]{2}{*}{72} & \multirow[b]{2}{*}{ GY-KTT-F } & \multirow[b]{2}{*}{$\begin{array}{l}\text { KTT } 78 \% \\
\text { GY } 12 \% \\
\text { SZG } 10 \%\end{array}$} & \multirow[b]{2}{*}{$\begin{array}{l}\text { növedék-fokozó } \\
\text { gyérítés } \\
(2005)\end{array}$} & égerliget & 1 \\
\hline & & & & & & $\begin{array}{l}\text { gyertyános- } \\
\text { kocsánytalan } \\
\text { tölgyes }\end{array}$ & - \\
\hline \multirow[t]{2}{*}{$122 \mathrm{D}$} & \multirow[t]{2}{*}{5,95} & felső Isz: 92 & \multirow[t]{2}{*}{ EF-F } & $\begin{array}{l}\text { EF } 87 \% \\
\text { JF 3\% } \\
\text { LF } 6 \% \\
\text { KTT } 4 \% \\
\end{array}$ & \multirow{2}{*}{$\begin{array}{l}\text { egészségügyi } \\
\text { fakitermelés } \\
(2010)\end{array}$} & égerliget & 1 \\
\hline & & alsó Isz: 8-9 & & $\begin{array}{l}\text { EF } 50 \% \\
\text { KTT } 35 \% \\
\text { B } 15 \%\end{array}$ & & $\begin{array}{l}\text { szubmontán } \\
\text { bükkös }\end{array}$ & 2 \\
\hline $123 \mathrm{E}$ & 5,48 & $62-72$ & GY-KTT-EL & $\begin{array}{l}\text { KTT 24\% } \\
\text { GY 38\% } \\
\text { B 5\% } \\
\text { SZG 9\% } \\
\text { KH 15\% } \\
\text { KNY 9\% }\end{array}$ & $\begin{array}{l}\text { növedék-fokozó } \\
\text { gyérítés } \\
(2015)\end{array}$ & $\begin{array}{l}\text { gyertyános- } \\
\text { kocsánytalan } \\
\text { tölgyes }\end{array}$ & 1 \\
\hline \multirow{2}{*}{$123 \mathrm{H}$} & \multirow{2}{*}{4,02} & \multirow{2}{*}{117} & \multirow{2}{*}{ VF } & \multirow{2}{*}{$\begin{array}{l}\text { VF } 54 \% \\
\text { B 20\% } \\
\text { KTT } 16 \% \\
\text { GY } 10 \%\end{array}$} & \multirow{2}{*}{$\begin{array}{l}\text { egészségügyi } \\
\text { fakitermelés } \\
(2014)\end{array}$} & égerliget & 1 \\
\hline & & & & & & $\begin{array}{l}\text { szubmontán } \\
\text { bükkös }\end{array}$ & 1 \\
\hline \multirow[b]{2}{*}{$126 \mathrm{E}$} & \multirow[b]{2}{*}{11,66} & \multirow[b]{2}{*}{57} & \multirow{2}{*}{ GY-KTT-B } & \multirow{2}{*}{$\begin{array}{l}\text { KTT 43\% } \\
\text { B 34\% } \\
\text { GY } 11 \% \\
\text { VT } 6 \% \\
\text { LF } 6 \%\end{array}$} & törzskiválasztó & égerliget & 1 \\
\hline & & & & & $\begin{array}{l}\text { gyérítés } \\
\text { (2004) }\end{array}$ & $\begin{array}{l}\text { szubmontán } \\
\text { bükkös }\end{array}$ & 1 \\
\hline
\end{tabular}




\section{Adatgyưjtés és a kiértékelés módszere}

A Tolvaj-árokban hosszában egyenletesen elosztott 4 keresztirányú transzekt mentén 14 mérési pontban, a Vadkan-árokban pedig a völgy lényegesen kisebb kiterjedésére való tekintettel 3 transzekt mentén felvett 8 mérési pontban történt a fekvő holt faanyag becslése.

Vizsgálataink során a vonal menti mintavétel (line intersect method) módszerét használtuk, Ódor 2005-ben erdőrezervátumokban végzett vizsgálatokra javasolt módszertanának alkalmazásával.

A módszer lényege, hogy egy kiválasztott mintapontból $3 \mathrm{db}$, egymástól $60^{\circ}$-ra kihúzott $20 \mathrm{~m}$ hosszú vonal mentén rögzítjük azon fák átmérőjét, amiket a vonal metsz. Csak meghatározott átmérőn felüli (általában $5 \mathrm{~cm}$ ) fák kerülnek felvételre. A rögzített átmérő adatok alapján a területre vonatkoztatott térfogatot az alábbi képlettel számolhatjuk ki: $V=\left(\pi^{\wedge} 2 \Sigma d^{\wedge} 2\right) / 8 L$, ahol $V$ az egységnyi területre vonatkoztatott térfogat, $d$ a fák átmérője, $L$ a vonal hossza. Számoláskor a mértékegységeket egységesíteni kell. A kapott eredményt 10000 -rel szorozva kapjuk meg a hektárra vetített köbtartalmat (Warren \& Olsen 1964, van Wagner 1968, Kirby et al 1998; Ódor 2005).

A mintavételezés során a mintevételbe kerülő tuskók felvételezése ugyanígy történt, amenyiben a vonal metszette azt akkor felvételezésre került.

A mintavételi pontokat, valamint az érintett erdőrészleteket QGIS Desktop 2.16.2 program segítségével ábrázoltuk grafikusan és helyeztük rá térképre. Az adatok kielemzése Microsoft Excel programmal történt.

A kiértékelés során minden mintavételi pontra meghatároztuk a holtfa hektárra eső térfogatát, majd transzektenként és mintaterületenként átlagolva kaptuk meg a vizsgált árkok eredményeit, valamint a szórást is megállapítottuk minden szempontnál. A fekvő holtfa térfogatának eloszlását elemeztük aktuális faállománytípus, korhadás, átmérőosztályok (5-10, 11-20, 21-30, 31-40, 41-50, 51-60, 61-70), és korcsoportok (fiatal 0-30, 31-70 középkorú és 70 felett idős állomány az erdőrészletek leíró lapjai alapján) alapján.

Ezen felül a Szmorad (2011) által szerkesztett potenciális vegetáció térképet alapul véve megállapítottuk az érintett erdőrészletek élőhelytípusát, majd aszerint elkülönítve a fekvő faanyag mennyiségét. A Tolvaj-árok területén 3 (égerligetek, gyertyános-kocsánytalan tölgyesek és szubmontán bükkösök), a Vadkan-árokban 2 (égerligetek és montán bükkösök) élőhelyet különítettünk el.

\section{EREDMÉNYEK}

A Tolvaj-árokban a fekvő faanyag átlagos mennyisége $30,66 \mathrm{~m}^{3} /$ ha a Vadkan-árokban pedig $21,23 \mathrm{~m}^{3} / \mathrm{ha}$, tehát a Tolvaj-árokban nagyobb a holtfa jelenéte. Mindkét területen kimondottan magas szórás $\left(30,38 \mathrm{~m}^{3} / \mathrm{ha}\right.$ a Tolvaj-árokban és $28,40 \mathrm{~m}^{3} / \mathrm{ha}$ a Vadkan-árokban) volt tapasztalható, ami a holt faanyag egyenetlen eloszlására utal a völgyekben. A fekvő holtfa az érintett erdőrészletek élőfakészletéhez viszonyítva átlagosan 13,19\% a Tolvaj-árokban, a Vadkan-árokban pedig 5,91\%-a.

A Vadkan-árokban a középkorú (30-70 éves) erdőrészletekben elöforduló holtfa értéke a legmagasabb $74,06 \%\left(43,74 \mathrm{~m}^{3} / \mathrm{ha}\right)$ értékkel. A Tolvaj-árokban a fiatalosoktól az idős állományok felé emelkedve a legmagasabb érték $54,34 \%\left(38,83 \mathrm{~m}^{3} / \mathrm{ha}\right)$ volt (2. ábra).

A fafajok előfordulását vizsgálva (3-6. ábra) a Tolvaj-árokban a legtöbb holt faanyagot a kocsánytalan tölgy adta $\left(10.00 \mathrm{~m}^{3} / \mathrm{ha}\right)$, emellett jelentős volt még az erdei fenyő $\left(5,08 \mathrm{~m}^{3} / \mathrm{ha}\right)$, a gyertyán $\left(4,42 \mathrm{~m}^{3} / \mathrm{ha}\right)$ és a mézgás éger $\left(3,64 \mathrm{~m}^{3} / \mathrm{ha}\right)$ is (4. ábra). A Vadkan-árokban pedig a mézgás éger $\left(9,77 \mathrm{~m}^{3} / \mathrm{ha}\right)$ és a lucfenyő $(6,79$ $\mathrm{m}^{3} / \mathrm{ha}$ ) mennyisége volt a legmagasabb (6. ábra).

Mindkét árokban nagy a fafajok változatossága a holt faanyagot tekintve (10, valamint 9 fajjal), és jelentős a fenyők előfordulása, a bükk viszont kifejezetten kevés. A Tolvaj-árokban a keményfák (3. ábra), a Vadkanárokban pedig a puhafák (5. ábra) domináltak $17,88 \mathrm{~m}^{3} /$ ha valamint $9,90 \mathrm{~m}^{3} /$ ha átlagos értékkel. 


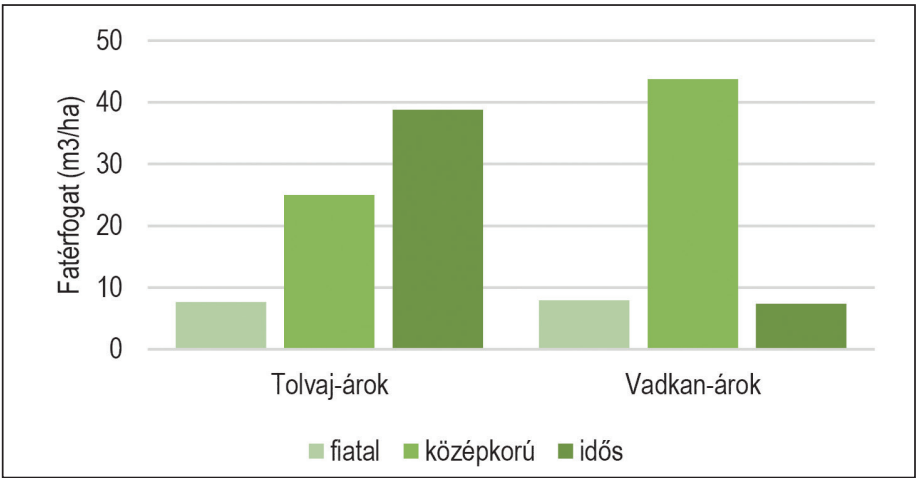

2. ábra: A fekvő holtfa az erdőrészletek kora szerint a két vizsgált mintaterületen

Figure 2: The amount of lying dead wood by stand ages in the two study areas

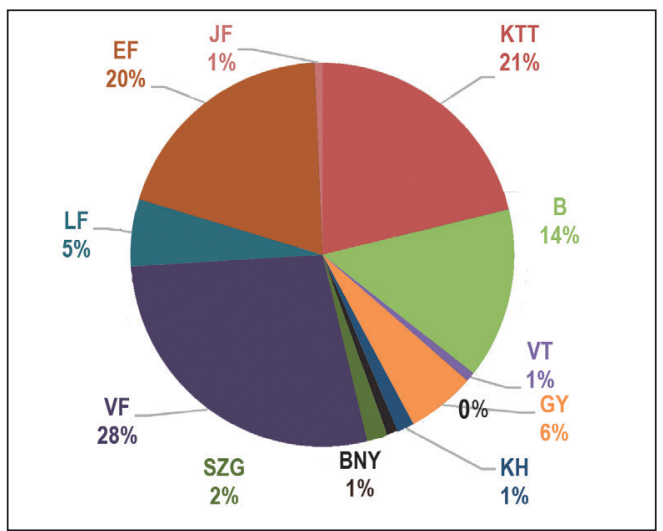

3. ábra: Az vizsgált erdőrészletek élőfakészletének fafajonkénti megoszlása hektáronként a Tolvaj-árokban ( $\left.\mathrm{m}^{3} / \mathrm{ha}\right)$

Figure 3: Distribution of live wood stock by tree species in the concerned stands in Tolvaj-árok $\left(\mathrm{m}^{3} / \mathrm{ha}\right)$

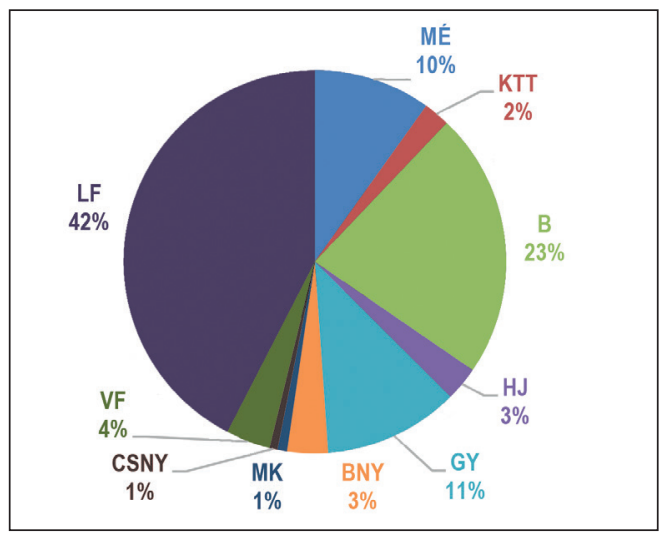

5. ábra: Az vizsgált erdőrészletek élőfakészletének fafajonkénti megoszlása hektáronként a Vadkan-árokban $\left(\mathrm{m}^{3} / \mathrm{ha}\right)$

Figure 5: Distribution of live wood stock by tree species in the concerned stands in Vadkan-árok $\left(\mathrm{m}^{3} / \mathrm{ha}\right)$

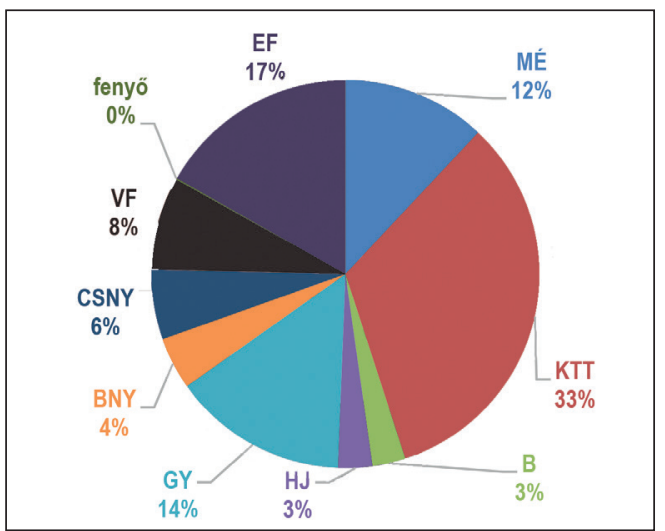

4. ábra: A fekvő holtfa fafajonkénti eloszlása a Tolvaj-árokban $\left(\mathrm{m}^{3} / \mathrm{ha}\right)$

Figure 4: The amount of lying dead wood by tree species in Tolvaj-árok $\left(\mathrm{m}^{3} / \mathrm{ha}\right)$

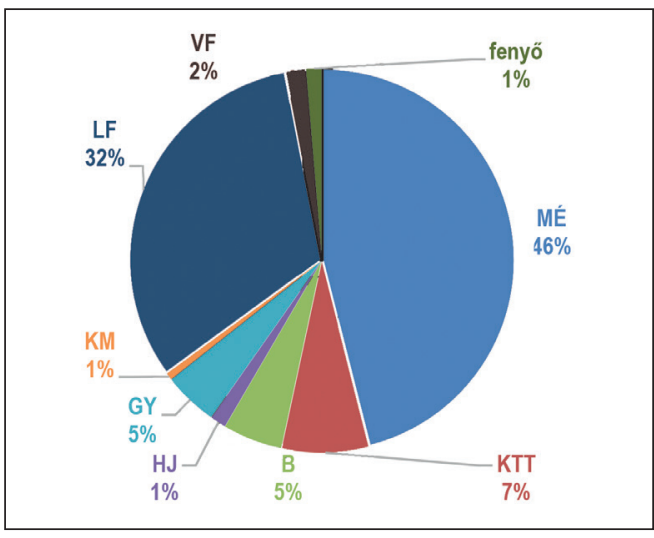

6. ábra: A fekvő holtfa fafajonkénti eloszlása a Vadkan-árokban ( $\left.\mathrm{m}^{3} / \mathrm{ha}\right)$

Figure 6: The amount of lying dead wood by tree species in Vadkan-árok $\left(\mathrm{m}^{3} / \mathrm{ha}\right)$ 
Amennyiben az érintett erdőrészletek fafajkészletét (3. és 5. ábra) összevetjük az árkokban mért holtfa adatokkal (4. és 6. ábra), feltűnik a mézgás éger magas aránya a holtfa értékeiben, kifejezetten a Vadkanárokban, ami egyértelmüen a patak közvetlen közelében végzett felméréseknek, és így az égeresek fokozott jelenlétének köszönhető, ami az egyes erdőrészletek leíró adatlapjain nem jelenik meg célfafajként. Emellett a Tolvaj-árokban a vörös fenyő, a Vadkan-árokban a lucfenyő magas jelenléte szembeötlő, valamint, hogy a bükk viszonylag kifejezett jelenléte ellenére kevésbé jelenik meg holt faanyagként.

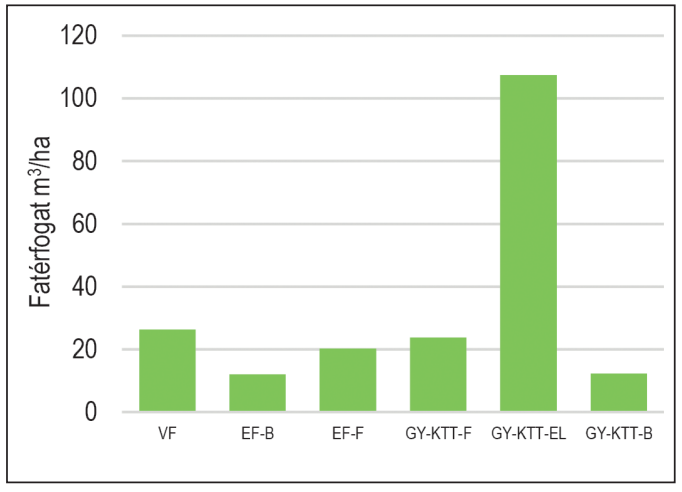

7. ábra: A fekvő holtfa aktuális faállománytípusok szerinti megoszlása a Tolvaj-árokban

Figure 7: The amount of lying dead wood by actual stand types in the Tolvaj-árok

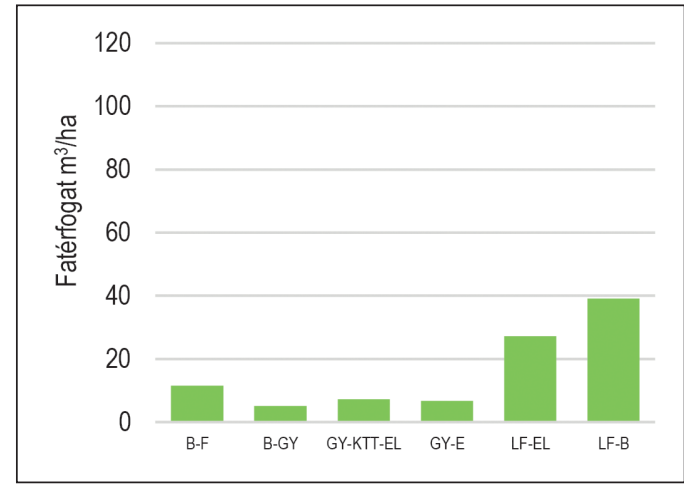

8. ábra: A fekvő holtfa aktuális faállománytípusok szerinti megoszlása a Vadkan-árokban

Figure 8: The amount of lying dead wood by actual stand types in the Vadkan-árok

Amennyiben a mintapontokkal érintett erdőrészletek aktuális faállománytípusát vizsgáljuk, a két árok között markáns különbségek fedezhetök fel. A Tolvaj-árokban az egyéb lombelegyes gyertyános-kocsánytalan tölgyesben mért érték kiemelkedő (53,16\%), emellett az egyéb faállománytípusok megoszlása hasonló. A Vadkan-árokban nem fedezhető fel ekkora különbség az egyes típusok között, ott a bükkös-lucfenyvesben mértük a legmagasabb értéket (40,39\%).

Korhadás alapján a Tolvaj-árokban az 1-es osztályba tartozó holtfák értéke (34,19\%) kiemelkedik (9. ábra), ráadásul, ha ezt az értéket összevetjük a 10. ábrával, látható, hogy a nagy mennyiségű friss faanyag a 61-70 cm-es kategóriában található.

Emellett a magasabb, 4-es és 5-ös korhadású fák értéke jelentősebb (22,93 és 15,21\%). A Vadkan-árokban a 2. korhadási fázis értékei jelentősebbek, átlagosan 40,07\%. Az érintett erdőrészletben 2015-ben volt fakitermelés, ez is okozhatja a kissé korhadtabb faanyag jelenlétét.

Az átmérőosztályok szerinti eloszlás tekintetében (10. ábra) mind a Tolvaj-árokban, mind a Vadkan-árokban a legtöbb a 11-20-as átmérőosztályba tartozó fa (42,63 és 36,03\%), a nagyobb kategóriákban a holtfa térfogata alacsony értékeket mutat, vagy hiányzik, kifejezetten a Vadkan-árokban, ahol $50 \mathrm{~cm}$ fölötti átmérővel rendelkező fa nem volt a mintavételben. A Tolvaj-árokban kitünik a 61-70-es kategóriába eső magas érték (22,93\%), amely egyetlen $70 \mathrm{~cm}$-es átmérőjü rönk előfordulására vezethető vissza.

Amennyiben a holtfa átmérőcsoportjait viszonyítjuk a korhadással, tapasztalható egy-egy kiugró érték, ami egy-egy nagyobb fához tartozik, így nagy mértében befolyásolhatja az eredményt. Mind a Tolvaj-árokban mind a Vadkan-árokban leolvashatók azok a vastag tuskók, amelyek megtalálhatók voltak a magasabb méretkategóriákban, amelyek mellett eltörpülnek az 5-10-es méretkategória példányai, hiába szerepelnek sokszoros darabszámmal. 


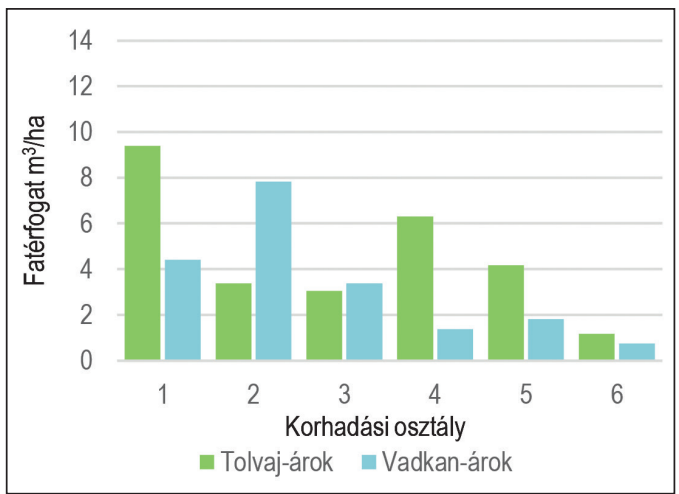

9. ábra: A fekvő holtfa korhadási osztályonként a két vizsgált mintaterületen

Figure 9: The amount of lying dead wood by decay classes in the two study areas

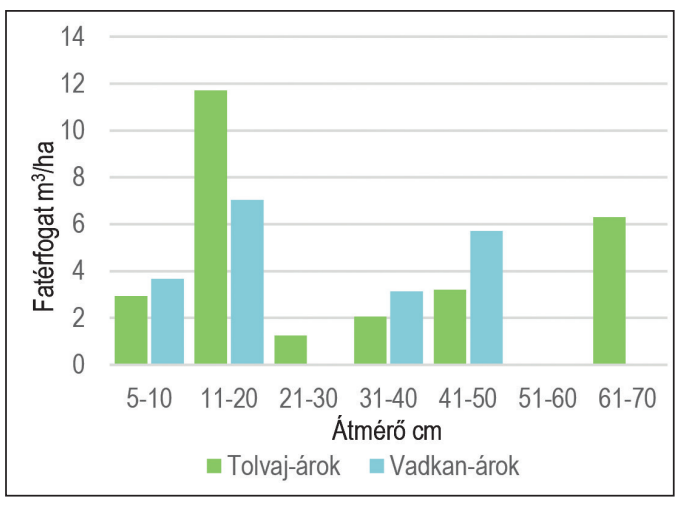

10. ábra: A fekvő holtfa átmérőcsoportok szerinti megoszlása a két vizsgált terület között

Figure 10: The amount of lying dead wood by diameter classes in the two study areas

A holt faanyagban kiemelkedően gazdag élőhelyek a gyertyános-kocsánytalan tölgyesek voltak, melyet a Vadkan-árok égerligetei követtek (11. és 12. ábra). Részben oka lehet ennek a másodlagos fafajok és a fenyők magas aránya, valamint az erdőállományok magasabb kora. Ennél a két élőhelytípusnál figyelhető meg a legnagyobb szórás is, amely a növényzet foltmintázatából adódhat. A legkevesebb pedig a Vadkan-árokban található montán bükkösökben volt, ennek oka valószínüleg az, hogy nagy részük fiatal vagy középkorú erdö, így még nem jutott el a szukcessziós fázisban odáig, hogy jelentős vastag fa felhalmozódás történjen benne.

Az égerligetek mindkét árokban viszonylag magas értékekkel szerepelnek (25,05 és 30,49 m³/ha), ennek több oka is lehet. Egyrészt mivel az erdők természetvédelmi rendeltetésűek, ezért a patak közvetlen környezetében, 25 méternél közelebb fakitermelés és faanyagkészletezés csak a természetvédelmi célokkal összhangban végezhető, így nagyobb a valószínűsége a faanyag területen hagyásának, valamint a terület völgy-jellegéből adódóan is felhalmozódik benne a faanyag.

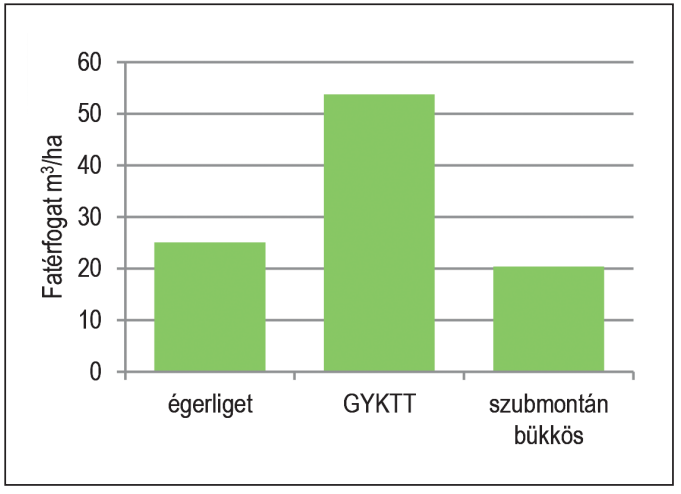

11. ábra: A fekvő holtfa megoszlása a potenciális élőhelytípusokban a Tolvaj-árokban

Figure 11: The amount of lying dead wood by decay classes in the two study areas

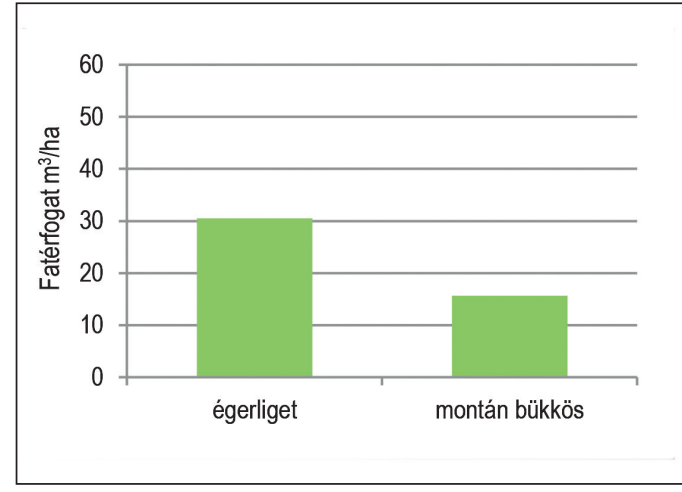

12. ábra: A fekvő holtfa megoszlása a potenciális élőhelytípusokban a Vadkan-árokban Figure 12: The amount of lying dead wood by diameter classes in the two study areas

Gazdasági erdőkben szintén fontos adat, hogy a felmérésbe bekerült tuskók adatai a számításokban mennyiben változtatnak a kapott eredményen. A Tolvaj-árokban 37,52 m³/ha, míg a Vadkan-árokban 30,48 
$\mathrm{m}^{3} /$ ha összesített térfogatértékeket eredményezett a tuskók beszámítása (ez a Tolvaj-árokban $6,86 \mathrm{~m}^{3} / \mathrm{ha}$, a Vadkan-árokban pedig $9,25 \mathrm{~m}^{3} /$ ha többletet jelent).

\section{KÖVETKEZTETÉSEK}

A holtfabecslés eredményeként a Tolvaj-árokban több faanyagot találtunk (30,66 m²/ha), a Vadkan-árokban pedig valamivel kevesebbet $\left(21,23 \mathrm{~m}^{3} / \mathrm{ha}\right)$. Ódor \& Standovár (2003) szerint a magyar gazdasági bükkösökben $30 \mathrm{~m}^{3} /$ ha az átlagos holtfamennyiség, ezt az értéket csak a Tolvaj-árok érte el. Ez az eredmény véleményem szerint elsősorban az állományok korával magyarázható, hiszen a Vadkan-árok erdőrészletei jóval fiatalabbak. Messze alulmarad viszont mind a Christensen et al (2005) által az európai lombhullató őserdő jellegű állományokra megállapított átlagtól (130 m³/ha), mind pedig a hazai bükki Öserdő erdőrezervátumtól, ahol természetközeli bükkösökben fekvő holtfára $137 \mathrm{~m}^{3} /$ ha értéket mértek (Ódor \& Standovár 2003). Magasabb holtfa értékeket várnánk, tekintve, hogy az érintett erdők mind természetvédelmi elsődleges rendeltetésűek és védettek vagy fokozottan védettek. A terület néhol igen meredek lejtőviszonyai megnehezítik a rajtuk található állományok kitermelését, valamint a letermelt faanyag mozgatását, ezzel lehetőséget teremtve a holtfa mennyiségének emelésére, ami azonban a területen nincs megfelelően kihasználva.

A vizsgált völgyekben a fafajok száma megfelelö, ám az erdőszerkezet változatossága mindenképpen növelendő, valamint a fenyőfélék jövőbeni további visszaszorulása lenne kívánatos, mivel arányuk még mindig igen magas a hegységben, annak ellenére, hogy egészségi állapotuk nem megfelelö.

Mivel a kapott kiemelkedő értékek sok esetben egy-egy nagyobb fának voltak köszönhetőek, a mintaelemszám további növelésével valószínűleg pontosabb becslést és kiegyenlítettebb eloszlást kaphatnánk a jövőben esetleges további vizsgálatok során. Mindkét terület képes megfelelő mennyiségű holtfa „előállítására”, tehát a fő hangsúly nem a holtfa előálításán kell, hogy legyen, hanem a keletkezett faanyag területen hagyásán, főként a minél korhadtabb fáknak, hiszen ezek gazdasági értéke csekély. Mivel a korhadt faanyaghoz kötődő szaproxyl fajok preferenciái változatosak, ezért nagyon fontos, hogy egy területen minden korhadási osztályból, valamint különböző méretű faanyagból rendelkezésre álljon megfelelő mennyiség. A felmért mintaterületeken ez a kritérium nem teljesül megfelelően, mindenképpen jó lenne, ha növekedne a korhadtabb faanyag jelenléte és diverzitása, ennek elősegítése a holtfa mennyiségének növelésével és minél több fának a területen hagyásával lehetséges, mivel főként keményfás fafajoknál hosszú folyamat az igazán korhadt fa kialakulása.

Több vizsgálat is alátámasztotta (Ódor \& Standovár 2003, Johnsson et al 2005, Jakoby et al 2010, Frank \& Szmorad 2014, Búzás 2015), hogy kis odafigyeléssel és a gyérítések gondosabb kivitelezésével gazdasági erdőkben is sokat lehet tenni egy terület biodiverzitásának holtfa visszahagyásával történő emeléséért.

Jakoby et al (2010) alapján érdemes lehet a lejtszög miatt nehezebben megközelíthető részeken holtfaszigetek létrehozása, akár kísérleti jelleggel. Kutatásai alapján egy min. 0,2 ha területű sziget már képes rá, hogy folyamatosan biztosítson holtfautánpótlást egy kezelt erdőben. A völgyoldal védelme érdekében különösen kímélni kell az arra merőlegesen kidőlt fákat, esetlegesen azok mesterséges elöállitását, ha szükséges, valamint figyelembe venni a Bobiec (2005) által javasolt irányszámokat a holtfa arányára (az élőfakészlet 15-20\%-a).

Tekintve, hogy az elvégzett vizsgálat elég speciális volt olyan szempontból, hogy két patakvölgy holtfa viszonyai kerültek felmérésre, mind a kapott eredmények, mind a terület értékelésekor ezt a völgyhelyzetet figyelembe kell vennünk, a teljesebb kép érdekében mindenképpen érdemes lehet további felméréseket végezni mind a környező állományokra, mind szélesebb körben a Soproni-hegység egyéb területeire vonatkozóan. 


\section{KÖSZÖNETNYILVÁNÍTÁS}

Köszönet illeti Dr. Tóth Viktóriát a kutatás során nyújtott rengeteg segítségért és támogatásért, Ambrus Andrást a felvételezésben hasznosnak bizonyuló EpiCollect alkalmazás személyre szabásáért és hasznos meglátásaiért, valamint Brolly Gábort a térinformatikai segítségnyújtásért. Ezen kívül Magyar Zsoltot és Szabó Károlyt a NÉBIH Erdészeti Igazgatóságtól, akik az erdőrészletekre vonatkozó adatokat szolgáltatták számunkra. Köszönet illeti továbbá Szerecz Pétert, aki a terepi felvételezések során nyújtott segítséget, emellett pedig Prof. Dr. Lakatos Ferencet, Dr. Csóka Györgyöt és Dr. Winkler Dánielt az építő jellegű kritikákért.

Jelen publikáció az „EFOP-3.6.1-16-2016-00018 - A felsőoktatási rendszer K+F+I szerepvállalásának növelése intelligens szakosodás által Sopronban és Szombathelyen" című projekt támogatásával valósult meg.

\section{FELHASZNÁLT IRODALOM}

Bartha D. \& Oroszi S. (eds) 2011: A Soproni-hegység erdőállományainak története. TAEG Tanulmányi Erdőgazdaság Zrt., Sopron.

Bidló A. \& Szűcs P. 2014: A holtfa szerepe az erdőállományok anyagforgalmában és talajfejlődésében. In: Csóka Gy. \& Lakatos F. (eds): A holtfa. Silva Naturalis 5., Nyugat-magyarországi Egyetem, Sopron, 177-190.

Bobiec A., Gutowski J.M., Laudenslayer W.F., Pawlaczyk P. \& Zub K. 2005: The afterlife of a tree. WWF Poland, WarsawaHajnóvka.

Bolla B. 2007: Víztani értékek a Vadkan-árokban. Diplomadolgozat. Nyugat-magyarországi Egyetem Erdőmérnöki Kar, Geomatikai, Erdőfeltárási és Vízgazdálkodási Intézet.

Bölöni J., Ádám R., Aszalós R. \& Ódor P. 2015: Holtfa az észak-magyarországi kezelt és felhagyott cseres-kocsánytalan tölgyesekben. In: Bölöni J. (ed): Tanulmányok a félszáraz tölgyesek ökológiai viszonyairól. MTA Ökológiai Kutatóközpont tanulmányai 1 ., Tihany.

Bölöni J. \& Ódor P. 2014: Mennyi holtfa van az erdőkben? In: Csóka Gy. \& Lakatos F. (eds): A holtfa. Silva Naturalis 5., Nyugat-magyarországi Egyetem, Sopron, 203-224.

Búzás E. 2015: Adatok a zánkai Bálint-hegy holtfa viszonyaihoz. Szakdolgozat. Pannon Egyetem Georgikon Kar Növénytudományi és Biotechnológiai Tanszék, Keszthely.

Christensen M., Hanh K., Mountford E.P., Ódor P., Standovár T., Rozenbergar D., Diaci J., Wijdeven S., Meyer P., Winter S. \& Vrska T. 2005: Dead wood in European beech (Fagus sylvatica) forest reserves. Forest Ecology and Management 210: 267-282. DOI: 10.1016/j.foreco.2005.02.032

Csóka Gy. 2011: A holtfa erdő- és természetvédelmi szerepe magyarországi keménylombos erdőkben. OTKA K68618 sz. pályázat zárójelentése.

Csóka Gy. 2014: A holtfa, mint életfeltétel. In: Csóka Gy. \& Lakatos F. (eds): A holtfa. Silva Naturalis 5., Nyugat-magyarországi Egyetem, Sopron, 45-48.

Csóka Gy., Lakatos F. \& Hirka A. 2014: Hogyan keletkezik a holtfa? In: Csóka Gy. \& Lakatos F. (eds): A holtfa. Silva Naturalis 5., Nyugat-magyarországi Egyetem, Sopron, 21-28.

De Meo I., Agnelli A. E., Graziani A., Kitikidou K., Lagomarsino A., Milios E., Radoglou K. \& Paletto A. 2017: Deadwood volume assessment in Calabrian pine (Pinus brutia Ten.) peri-urban forests: Comparison between two sampling methods, Journal of Sustainable Forestry DOI: 10.1080/10549811.2017.1345685

Dövényi Z. (ed) 2010: Magyarország kistájainak katasztere. MTA Földrajztudományi Kutatóintézet, Budapest

Dynesius M., Gibb H. \& Hjältén J. 2010: Surface Covering of Downed Logs: Drivers of a Neglected Process in Dead Wood Ecology. Plos One 5(10): e13237. DOI: 10.1371/journal.pone.0013237

Frank T. \& Szmorad F. 2014: Védett erdők természetességi állapotának fenntartása és fejlesztése. Rosalia kézikönyvek 2. Duna-Ipoly Nemzeti Park Igazgatóság, Budapest.

Gribovszki Z., Kalicz P. \& Kucsara M. 2014: A holt faanyag hatása a vízfolyásokra. In: Csóka Gy. \& Lakatos F. (eds): A holtfa. Silva Naturalis 5., Nyugat-magyarországi Egyetem, Sopron, 191-196.

Hodge S.J. \& Peterken G.F. 1998: Deadwood in British forests: priorities and a strategy. Forestry 71(2): 99-112. DOl: 10.1093/forestry/71.2.99 
Jakoby O., Rademacher C. \& Grimm V. 2010: Modelling dead wood islands in European beech forests: how much and how reliably would they provide dead wood? European Journal of Forest Research 129: 659-668. DOI: 10.1007/s10342010-0366-3

Johnsson B.G., Kruys N. \& Ranius T. 2005: Ecology of species living on dead wood - Lessons for dead wood management. Silva Fennica 39(2): 289-309. DOI: 10.14214/sf.390

Keren S. \& Diaci J. 2018: Comparing the quantity and structure of Deadwood in Selection Managed and Old-Growth Forests in South-East Europe. Forests 9: 76, DOI: 10.3390/f9020076

Király G. 2004: A Soproni-hegység edényes flórája. Flora Pannonica, II(1): 1-509.

Király G. 2008: Soproni-hegység. In: Király G., Molnár Zs., Bölöni J., Csiky J., Vojtkó A. (eds): Magyarország földrajzi kistájainak növényzete. MTA ÖBKI, Vácrátót, 91.

Kirby K.J., Reid C.M., Thomas R.C. \& Goldsmith F.B. 1998: Preliminary estimates of fallen dead wood and standing dead trees in managed and unmanaged forests in Britain. Journal of Applied Ecology 35: 148-155. DOI: 10.1046/j.13652664.1998.00276.x

Kraigher H., Jurc D., Kalan P., Kutnar L., Levanic T., Rupel M. \& Smolej I. 2003: Beech coarse woody debris characteristics in two virgin forest reserves in southern Slovenia. Nat-Man Working Report 26.

Lakatos F. 2006: Fenyőállományokban végrehajtott egészségügyi termelések szerepe védett és/vagy veszélyeztetett fában és kéregben költő bogárfajok esetén (Coleoptera). Természetvédelmi Közlemények 12: 123-131.

Lakatos F. \& Csóka Gy. 2014: A holtfa és az erdő egészsége. In: Csóka Gy. \& Lakatos F. (eds): A holtfa. Silva Naturalis 5. Nyugat-magyarországi Egyetem, Sopron, 197-202.

Mag Zs., Ódor P. 2015. The effect of stand-level habitat characteristics on breeding bird assemblages in Hungarian temperate mixed forests. Community Ecology 16: 156-166. DOI: 10.1556/168.2015.16.2.3

Merganicová K., Merganic J., Svoboda M., Bace R. \& Seben V. 2012: Deadwood in Forest Ecosystems. In Blanco J.A. (ed): Forest Ecosystems - More than Just Trees. InTech, Available from: http://www.intechopen.com/books/forestecosystems-more-than-just-trees/deadwood 2016.10.31. DOI: 10.5772/31003

Merkl O. 2016: A szaproxilofág bogarak (Coleoptera) szerepe a holtfa lebontásában. In: Korda M. (ed): Az erdőgazdálkodás hatása az erdők biológiai sokféleségére. Duna-Ipoly Nemzeti Park Igazgatóság, Budapest, 129-154.

Mikó Á. \& Csóka Gy. 2016: A hangyák szerepe a magyarországi erdei ökoszisztémákban. In: Korda M. (ed): Az erdőgazdálkodás hatása az erdők biológiai sokféleségére. Duna-Ipoly Nemzeti Park Igazgatóság, Budapest, 109-128.

Ódor P. 2005: Javaslat a fekvő holt fa szisztematikus mérésére az erdőrezervátumokban. Kutatási jelentés, kézirat.

Ódor P. 2016: Az erdei biodiverzitást meghatározó tényezők az Őrségi Nemzeti Parkban. In: Korda M. (ed): Az erdőgazdálkodás hatása az erdők biológiai sokféleségére. Duna-Ipoly Nemzeti Park Igazgatóság, Budapest, 603-624.

Ódor P. \& Standovár T. 2003: Changes of physical and chemical properties of dead wood during decay. Nat-Man Working Report 24.

Ódor P., van Hees A.F.M., Heilmann-Clausen J., Christensen M., Aude E., van Dort K.W. Piltaver A.,. Siller I., Veerkamp M.T., Walleyn R., Standovár T., van Hees A.F.M., Kosec J., Matočec N., Kraigher H. \& Grebenc T. 2004: Ecological Succession of Bryophytes, Vascular Plants and Fungi on Beech Coarse Woody Debris in Europe. Nat-Man Working Report 50.

Ónodi G. \& Winkler D. 2014: A holtfa szerepe az odúlakó madárközösségek kialakulásában In: Csóka Gy. \& Lakatos F. (eds): A holtfa. Silva Naturalis 5., Nyugat-magyarországi Egyetem, Sopron, 125-144.

Preikša Z., Brazaitis G., Marozas V., Jaroszewicz B. 2015: Dead wood quality influences species diversity of rare cryptogams in temperate broadleaved forests. iForest (early view). - DOI: 10.3832/ifor1483-008 [online 2015-09-28]

Puletti N., Giannetti F., Chirici G. \& Canullo R. 2017: Deadwood distribution in European Forests. Journal of Maps 13(2) 733-736. DOI: 10.1080/17445647.2017.1369184

Rondeux J. \& Sanchez C. 2009: Review of indicators and field methods for monitoring biodiversity within national forest inventories. Core variable: Deadwood. Environmental Monitoring and Assessment, 164(1-4): 617-630. DOI: 10.1007/ s10661-009-0917-6

Schuck A., Meyer P., Menke N., Lier M. \& Lindner M. 2004: Forest Biodiversity Indicator: Dead Wood - A Proposed Approach towards Operationalising the MCPFE Indicator. In: Marchetti M. (ed): Monitoring and indicators of Forest Biodiversity in Europe - From Ideas to opportunity. EFI Proceedings 51: 49-77.

Sefidi K. \& Etemad V. 2015: Dead wood characteristics influencing macrofungi species abundanceand diversity in Caspian natural beech (Fagus orientalis Lipsky) forests. Forest Systems 24(2): eSC03. DOI: 10.5424/fs/2015242-06039 
Somogyi Z. 1998: A bolygatás jelentősége, szerepe az erdei ökoszisztémákban és erdőművelési jelentősége. Erdészeti Kutatások 88: 165-194.

Standovár T. \& Kenderes K. 2003: A review on natural stand dynamics in beechwoods of east central Europe. Applied Ecology and Environmental Research 1(1-2): 19-46. DOI: 10.15666/aeer/01019046

Stokland J.N., Siitonen J., \& Jonsson B.G. 2012: Biodiversity in dead wood. Cambridge University Press. DOI: 10.1017/ cbo9781139025843

Stockland J.N., Tomter S.M. \& Söderberg U. 2004: Development of Dead Wood Indicators for Biodiversity Monitoring: Experiences from Scandinavia. In: Marchetti M (ed): Monitoring and Indicators of Forest Biodiversity in Europe - From Ideas to Opportunity. EFI Proceedings 51: 207-226.

Svensson M., Johansson V., Dahlberg A., Frisch A., Thor G. \& Ranius T. 2015: The relative importance of stand and dead wood types for wood-dependent lichens in managed boreal forests. Fungal Ecology DOI: 10.1016/j.funeco.2015.12.010

Szmorad F. 2011: A Soproni-hegység erdeinek történeti, növényföldrajzi és cönológiai vizsgálata. Tilia 16: 1-272.

Tímár G. 2016: Erdei mikroélőhelyek és védelmük lehetőségei az erdőgazdálkodás során. In: Korda M. (ed): Az erdőgazdálkodás hatása az erdők biológiai sokféleségére. Duna-Ipoly Nemzeti Park Igazgatóság, Budapest, 533-548.

Tóth V. 2014: A holtfán történő felújulás jelentősége az erdőkben. In: Csóka Gy. \& Lakatos F. (eds): A holtfa. Silva Naturalis 5., Nyugat-magyarországi Egyetem, Sopron, 171-176.

Vacek S., Vacek Z., Bílek L., Hejcmanová P., Stícha V. \& Remes J. 2015: The dynamics and structure of dead wood in natural spruce-beech forest stand - a 40 year case study in the Krokonose National Park. Dendrobiology 73: 21-32. DOI: $10.12657 /$ denbio. 073.003

van Wagner C.E. 1968: The line intersect method in forest fuel sampling. Forest Science 14: 20-26.

Warren W.G. \& Olsen P.F. 1964: A line intersect technique for assessing logging waste. Forest Science 10: 267-276. DOI: 10.1093/forestscience/14.1.20

Winkler D. 2000: A madárközösségek, mint bioindikátorok alkalmazási lehetősége. In: Frank T. (ed): Természet - Erdő Gazdálkodás. Magyar Madártani és Természetvédelmi Egyesület \& Pro Silva Hungaria Egyesület, Eger, 163-167.

Winkler D. 2005: Ecological succession of breeding bird communities in deciduous and coniferous forests in the Sopron Mountains, Hungary. Acta silvatica \& Lignaria Hungarica 1: 49-58.

Érkezett: 2018. március 31.

Közlésre elfogadva: 2018. július 9. 